Валіулліна 3. В., к.е.н., доцент кафедри міжнародних

економічних відносин (Національний університет водного господарства та природокористування, м. Рівне)

\title{
ІНФОРМАТИЗАЦІЯ У ЗАБЕЗПЕЧЕННІ РЕЗУЛЬТАТИВНОСТІ КОРПОРАТИВНОГО УПРАВЛІННЯ
}

У статті досліджено вплив інформаційних технологій на результативність корпорацій. Визначено, що одним із загальновизнаних в світі шляхів забезпечення результативності корпоративного управління $\epsilon$ інформатизація. Проаналізовано особливості корпоративного менеджменту американських корпорацій та показники міжнародного виробництва. Доведено, що сучасними конкурентними перевагами корпорацій $є$ використання інформаційнокомунікаційних технологій.

Ключові слова: інформатизація, інформаційне середовище, корпоративне управління, ефективність управління, корпорація.

Постановка проблеми. Сучасний етап розвитку українських підприємств характеризується інтеграційними процесами та ставить перед собою основні завдання серед яких швидке підвищення конкурентоспроможності та інвестиційної привабливості через призму інформатизації корпоративного управління.

В умовах інформаційної глобалізації інформація є вирішальним і єдиним засобом подолання проблем побудови результативних корпорацій в ринкових відносинах з гармонізацією взаємодії між власниками корпорацій, кредиторами, потенційними інвесторами, постачальниками, споживачами, співробітниками корпорації, представниками державних органів влади та громадськими організаціями. Тому, вивчення питання ефективного корпоративного управління через призму інформатизації $є$ актуальним та важливим як $з$ теоретичної, так і практичної точок зору.

Аналіз останніх досліджень. Проблемам інформатизації у корпораціях присвячені теоретичні доробки вітчизняних вчених та вчених-економістів світового рівня серед яких Л.М. Варава [1], А. Дж. Кошеев [2], Ас. А. Альборов [2], В. Кравченко [3], О. М. Сазонець [4], І.Л. Сазонець, Н.С. Орлова [5], Ю.Л. Мохова [5] та інші.

Метою даної статті є доведення необхідності формування ефективного та результативного корпоративного управління з урахуван- 
ням сучасних інформаційних технологій для підвищення конкурентоспроможності вітчизняних підприємств та залучення інвестицій.

Виклад основного матеріалу. Нині в розвинених країнах уже чітко визначено основи системи відносин між головними дійовими особами моделі корпоративного управління: акціонерами, менеджерами, директорами, кредиторами, державними установами тощо. Така система створюється для вирішення основних завдань корпорації: забезпечення їі максимальної ефективності; залучення інвестицій; виконання юридичних і соціальних зобов'язань [6, С. 45].

Досліджуючи праці американських вчених, можна зазначити, що на їх думку, американська корпоративна система також $є$ найбільш інформатизованою. Р. Уотермен у монографії «Фактор оновлення або як підтримують конкурентоспроможність кращі корпорації» визначив окремі особливості корпоративного менеджменту американських корпорацій та виокремив серед них інформаційну складову [7]. Так, науковець вважає, що:

1. Стратегія американської корпорації є продовженням політики так званого «інформаційного опортунізму». Під цим терміном автор розуміє використання інформованості як фактора управління у поєднанні з використанням випадкових факторів зовнішнього середовища, які необхідно використовувати корпораціям на свою користь;

2. Ще одним чинником конкурентоспроможності корпорації автор вважає необхідність постійного навчання персоналу та інформаційне наповнення системи управління. Це інформаційне наповнення повинно ефективно використовуватись компетентними фахівцями;

3. Важливим чинником $є$ використання інтелектуального капіталу корпорації з метою розробки стратегії її розвитку;

4. Особливістю управління в американських корпораціях автор вважає запровадження навчання фахівців менеджменту та перепідготовки у нестабільних умовах діяльності корпорації та загальної економічної ситуації;

5. Важливим елементом стратегії управління автор вважає також збереження простоти стратегії корпорації та незмінність загальних цінностей корпорації;

6. Важливим чинником використання інформації в управлінні автор вважає навчання в умовах експериментів, що можуть проводитись в менеджменті корпорації або в ії виробництві;

7. Стратегія діяльності корпорації повинна формуватися також з урахуванням зворотного впливу економічних та соціальних факторів на дії корпорації;

8. На думку автора, лише незначна кількість персоналу у службах менеджменту корпорації досконало володіє статистичними ме- 
тодами, що призводить до прийняття управлінських рішень, які ґрунтуються на незначній інформаційній базі та великому емпіричному досвіді. Рекомендацією автора є максимальне розширення використання статистичних методів в практиці управління;

9. За думкою автора, більшість менеджерів переоцінюють власну інформованість та компетентність в тих питаннях, що доводиться їм вирішувати в корпорації. Тому будь-які управлінські рішення не можуть бути абсолютно позитивними;

10. Необхідність упорядкування інформації всередині корпорації обумовлена тим, що хаотичні явища в управлінні можуть виникати не тільки на основі дій зовнішнього середовища, але й завдяки неузгодженості дій менеджерів корпорацій з різних структурних підрозділів;

11. Однією з найбільш корисних функцій корпорації є генерування інформації. Це генерування міститься у створенні нових пропозицій та ідей і визначенні шляхів їх реалізації;

12. Інформація $€$ головною стратегічною перевагою корпорації. Корпорація не повинна економити кошти на процесі генерування інформації;

13. Інформація є важливим чинником діяльності корпорації, але їі обробка повинна спиратися як на статистичну, аналітичну складову, так і мати інтуїтивний характер;

14. Інтуїція в управлінні, за думкою автора, є проявом довгорічного накопичення інформації та досвіду менеджера, проявом високого рівня його творчої професійної складової;

15. Професійна інформація повинна бути основою для процесу планування в корпорації;

16. До одного з головних індикаторів, що висвітлює ефективність корпоративного менеджменту, відноситься рівень комунікацій та наявність запровадження нових засобів комунікацій [4, С. 81-86].

Таким чином, необхідно зазначити, що:

- всі визначені риси сучасного корпоративного управління, які притаманні головним світовим моделям, грунтуються на процесах глобалізації, що стимулюються в тому числі і інформатизацією світогосподарського розвитку;

- всі етапи здійснення процедур корпоративного управління пов'язані на теперішній час з використанням інформаційних технологій. Характер чинників, що сприяють проникненню інформаційних технологій в процеси корпоративного управління, слід визначити як об'єктивний та універсальний;

- всі пріоритетні напрями роботи управлінських служб кор- 
порації в процесі реалізації процедур корпоративного управління слід визначити такими, що тісно пов'язані з інформаційною діяльністю. Особливо це стосується діяльності незалежних реєстраторів;

- всі корпоративні моделі світу спираються на інформаційну діяльність, але в сфері корпоративного управління найбільш інформаційноємною моделлю є англо-американська або саксонська модель. Це зумовлено найбільш повним розкриттям інформації в процесі корпоративного управління та політикою «інформаційного опортунізму», яку проводять менеджери американських корпорацій.

Крім того, бурхливий розвиток корпорацій як окремих суб'єктів міжнародного бізнесу заклав основи для формування особливих інститутів світової економіки - специфічних об'єднань міжнародних підприємств (трести, картелі, синдикати, холдинги, спільні підприємства). Дані процеси перетворили корпорації у власників значних активів, контрольованих материнськими компаніями, що дало змогу сконцентрувати владу в руках найбільших корпорацій та контролювати процеси міжнародного виробництва, розподілу та збуту товарів і послуг. Дані процеси виявляються у швидких темпах зростання світового виробництва, світової торгівлі товарами та послугами, зростання частки світового ВВП, створеного за рахунок діяльності приватного сектору (таблиця).

Відмітимо, що технологічні зміни відкрили нові двері для сфери послуг, створюючи нові потенційні ринки для експансії ТНК та нові послуги, які забезпечують прямий зв'язок між виробниками та споживачами. Зокрема, йде мова про активну роль корпорацій у сфері інформатизації світової економіки, що стала важливою тенденцією розвитку світового господарства поряд із глобалізацією, інтеграцією та транснаціаналізацією. Бурхливий розвиток інформаційних, комп'ютерних і комунікаційних технологій призвів до прискорення процесів інтернаціоналізації міжнародного виробництва корпорацій та поглиблення глобального розподілу праці.

Таблиця

Показники міжнародного виробництва та діяльності ТНК, млрд дол. США*

\begin{tabular}{|l|c|c|c|c|c|c|}
\hline \multicolumn{1}{|c|}{ Показники } & 1982p. & 1990p. & $\begin{array}{c}\text { 2005-2007pp. } \\
\text { (середні) }\end{array}$ & 2010p. & 2015p. & $2016 \mathrm{p}$. \\
\hline Вхідні ПІІ & 58 & 207 & 1491 & 1409 & 1774 & 1746 \\
\hline Вихідні ПІІ & 27 & 239 & 1534 & 1505 & 1594 & 1452 \\
\hline Накопичені залучені ПII & 790 & 1942 & 14706 & 20380 & 25191 & 26728 \\
\hline Накопичені вкладені ПII & 579 & 1786 & 15895 & 21130 & 24925 & 26160 \\
\hline Дохід від залучених ПІІ & 44 & 74 & 1076 & 1377 & 1480 & 1511 \\
\hline
\end{tabular}


продовження таблиці

\begin{tabular}{|l|c|c|c|c|c|c|}
\hline Дохід від вкладених ПІІ & 46 & 120 & 1148 & 1387 & 1382 & 1376 \\
\hline $\begin{array}{l}\text { Транскордонні злиття та } \\
\text { поглинання }\end{array}$ & - & 200 & 703 & 344 & 735 & 869 \\
\hline $\begin{array}{l}\text { Обсяги продажів закор- } \\
\text { донних підрозділів }\end{array}$ & 2741 & 6036 & 19579 & 22574 & 36069 & 37570 \\
\hline $\begin{array}{l}\text { Вартість активів закор- } \\
\text { донних підрозділів }\end{array}$ & 2036 & 6036 & 43836 & 78631 & 108621 & 112833 \\
\hline $\begin{array}{l}\text { Експорт закордонних } \\
\text { підрозділів }\end{array}$ & 688 & 1523 & 5003 & 6320 & 6974 & 6812 \\
\hline $\begin{array}{l}\text { Зайнятість у закордонних } \\
\text { підрозділах (тис. осіб) }\end{array}$ & 21524 & 24476 & 51795 & 63043 & 79817 & 82140 \\
\hline
\end{tabular}

*_ складено автором за джерелом [8]

Швидкі технологічні зміни, що ведуть до скорочення життєвого циклу продукту, зробили інновації та технології ключовим джерелом конкурентної сили корпорацій. Компанії вдаються до різних дій, тактик та стратегій щоб досягти високого технологічного рівня як процесу виробництва, так і самого продукту, i, тим самим, підтримувати власну конкурентоспроможність. У результаті масштаби діяльності корпорацій все більше перевершують національні межі, причому не лише у процесах виробництва та маркетингу, але в технологічних досягненнях, дослідженнях та розробках. Зближення споживчих потреб в умовах глобальної економіки, особливо в інформаційній сфері, міжнародна дифузія технологій вплинули як на темп, так і на фокус змін у діяльності корпорацій. Компанії дійшли до усвідомлення того, що національне середовище економічного розвитку вже не може забезпечити найсучасніші технологічні можливості, інноваційний розвиток та сприятливе інформаційне середовище. Сьогодні нові потреби, виклики або тенденції можуть виникнути на будь-якому ринку, інколи територіально абсолютно відділеному, а сучасні новітні технології можуть бути розташовані на іншому. Тому серед основних завдань сучасних корпорацій на сьогодні $€$ прагнення отримати нові конкурентні переваги за рахунок використання інформаційнокомунікаційних технологій, всебічного використання потреб інформатизації світової економіки.

Висновки. Отже, використовуючи сучасні засоби інформатизації, корпорації виходять на новий, віртуальний рівень, що проявляється перш за все у використанні глобальних електронних мереж для передачі та обміну даними під час реалізації власних операцій. Зокрема, найпопулярніший серед засобів - Інтернет-мережа - спри- 
яла розширенню діапазону комерційних відносин. Електронна комерційна діяльність дозволяє сучасним компаніям здійснювати транскордонні операції на більш ефективному рівні, тісніше взаємодіяти 3 глобальними постачальниками та значно швидше реагувати на мінливі запити споживачів.

Крім того, результати проведеного дослідження показали, що у подальших прогнозах розвитку ринку інформаційних технологій домінують саме сектори софту та послуг IT-консалтингу з незначною динамікою. Так, фахівці Forrester очікують зростання витрат корпорацій та інших суб'єктів глобальної економіки на придбання програмного та апаратного забезпечення, а також сервісів у глобальному масштабі.

1. Напрями розвитку сучасного менеджменту: проблеми та рішення : монографія / Л. М. Варава, В. Я. Нусінов та ін.; за заг. ред. д-ра екон. наук, проф. Л. М. Варави. Кривий Ріг : Видавець ФО-П Чернявський Д.О. 2015. 417 с. 2. Кошеев А. Дж. Методические подходы информационного обеспечения разработки стратегий управления предприятием А. Дж. Кошеев, Ас. А. Альборов. Terra Economicus. 2011. № 4. Ч. 3. Т. 9. С. 91-94. 3. Кравченко В. Влияние институциональной среды на динамику стоимости корпоративного предприятия. Бюлетень Міжнародного Нобелівського економічного форуму. 2013. № 1. С. 178-181. 4. Сазонець О. М. Методологічні засади формування інформаційної системи ТНК. Актуальні проблеми економіки. 2011. № 12(126). С. 43-49. 5. Орлова Н. С., Мохова Ю. Л. Впровадження інформаційних технологій в систему корпоративного управління. Відкрите освітнє е-середовище сучасного університету. №3 (2017). URL: http://openedu.kubg.edu.ua/journal/index.php/openedu/article/ viewFile/102/138 (дата звернення: 15.01.2019). 6. Гриньова В. М., Попов О.Є. Організаційно-економічні основи формування системи корпоративного управління в Україні : монографія. Х. : ХДЕУ, 2009. 324 с. 7. Уотермен Р. Фактор обновления : пер. с англ. / общ. ред. В. Г. Рысина. М. : Прогресс, 1988. 368 с. 8. The United Nations Conference on Trade and Development (UNCTAD). World Investment Reports. Electronic source. Mode of access: http://unctad.org/en /pages/DIAE/World\%20Investment\%20Report/WIR-Series.aspx. (дата звернення: 15.01.2019).

\section{REFERENCES:}

1. Napriamy rozvytku suchasnoho menedzhmentu: problemy ta rishennia : monohrafiia / L. M. Varava, V. Ya. Nusinov ta in.; za zah. red. d-ra ekon. nauk, prof. L. M. Varavy. Kryvyi Rih : Vydavets FO-P Cherniavskyi D.0. 2015. 417 c. 2. Kosheev A. Dzh. Metodicheskie podkhody informatsionnoho obespecheniia razrabotki stratehii upravleniia predpriiatiem A. Dzh. Kosheev, As. A. Alborov. 
Terra Economicus. 2011. № 4. Ch. 3. T. 9. S. 91-94. 3. Kravchenko V. Vliianie institutsionalnoi sredy na dinamiku stoimosty korporativnoho predpriiatiia. Biuleten Mizhnarodnoho Nobelivskoho ekonomichnoho forumu. 2013. № 1. S. 178-181. 4. Sazonets 0. M. Metodolohichni zasady formuvannia informatsiinoi systemy TNK. Aktualni problemy ekonomiky. 2011 . № 12 (126). S. 43-49. 5. Orlova N. S., Mokhova Yu. L. Vprovadzhennia informatsiinykh tekhnolohii $\mathrm{v}$ systemu korporatyvnoho upravlinnia. Vidkryte osvitnie eseredovyshche suchasnoho universytetu. № 3 (2017). URL: http://openedu.kubg.edu.ua/journal/index.php/openedu/article/

viewFile/102/138 (data zvernennia: 15.01.2019). 6. Hrynova V. M., Popov O. Ye. Orhanizatsiino-ekonomichni osnovy formuvannia systemy korporatyvnoho upravlinnia v Ukraini : monohrafiia. Kh. : KhDEU, 2009. 324 s. 7. Uotermen R. Faktor obnovleniia : per. s anhl. / obshch. red. V. H. Rysina. M. : Prohress, 1988. 368 s. 8. The United Nations Conference on Trade and Development (UNCTAD). World Investment Reports. Electronic source. Mode of access: http://unctad.org/en/pages/DIAE/World\%20Investment\%20Report/WIRSeries.aspx. (data zvernennia: 15.01.2019).

Рецензент: д.е.н., професор Сазонець І. Л. (НУВГП)

Valiullina Z. V., Candidate of Economics (Ph.D.), Associate Professor of the Department of International Economic Relations (National University of Water and Environmental Engineering, Rivne)

\section{INFORMATIZATION IN PROVIDING CORPORATE GOVERNANCE RESPONSIBILITY}

The aim of the research is to prove the necessity of the effective corporate management taking into account modern information technologies for increasing the competitiveness of internal enterprises and attraction of the investments.

The theoretical and methodological basis of the research is the fundamental principles of information technologies in the economy, scientific works of native and foreign scientists on the issues of corporate governance improvement.

The article investigates the influence of information technologies on the performance of corporations. It is determined that one of the most recognized ways in the world to ensure the effectiveness of corporate governance is informatization. The peculiarities of corporate management of American corporations and indicators of international production are analyzed. It has been determined that rapid technological changes lead to a shorter product life cycle, and 
innovation and technology are today the key source of competitive power of corporations. It is proved that the current competitive advantages of corporations are the use of information and communication technologies.

Keywords: informatization, information environment, corporate governance, management efficiency, corporation.

Валиуллина 3. В., к.э.н, доцент кафедры международной экономики (Национальный университет водного хозяйства и природопользования, г. Ровно)

\section{ИНФОРМАТИЗАЦИЯ В ОБЕСПЕЧЕНИИ РЕЗУЛЬТАТИВНОСТИ КОРПОРАТИВНОГО УПРАВЛЕНИЯ}

В статье исследовано влияние информационных технологий на результативность корпораций. Определено, что одним из общепризнанных в мире путей обеспечения результативности корпоративного управления является информатизация. Проанализированы особенности корпоративного менеджмента американских корпораций и показатели международного производства. Доказано, что современными конкурентными преимуществами корпораций является использование информационно-коммуникационных технологий.

Ключевые слова: информатизация, информационная среда, корпоративное управление, эффективность управления, корпорация. 